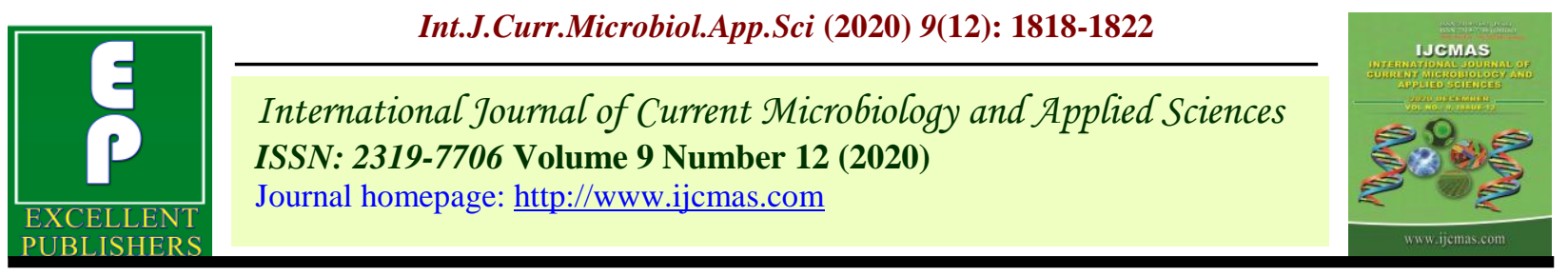

Original Research Article

https://doi.org/10.20546/ijcmas.2020.912.216

\title{
An Analysis of Warehousing Development and Trends in Storage of Major Food Grain in NBHC Jaipur District
}

\author{
Lokendra Singh Naruka*, Amit Kumar and Vaibhav
}

Sam Higginbottom University of Agriculture, Technology and Sciences, Prayagraj Uttar Pradesh-211007, India

*Corresponding author

\section{A B S T R A C T}

\begin{tabular}{l} 
Ke y w or d s \\
NBHC, Major food \\
grain, \\
Omniflow, \\
Mandat \\
\hline Article Info \\
\hline $\begin{array}{l}\text { Accepted: } \\
14 \text { November } 2020 \\
\text { Available Online: } \\
10 \text { December } 2020\end{array}$ \\
\hline \hline
\end{tabular}

The present study is restricted to NBHC's branch of Jaipur district of Rajasthan state and carried out in the year 2019. 50 traders were selected for the study of warehouse space availability, from the selected 5 mandies as working area of NBHC and 50 farmers were selected for the study of marketable and marketed surplus of food grain, from 3 major food grain production taluka of Jaipur district. It is observed that NBHC follows the operational practices in a very good manner, which required for a good warehousing business. NBHC deals in some services named as professional warehousing, collateral management services, quality and certification, commodity care and pest control and trade facilitation. NBHC have own in-house ERP (OMNIFLOW) for recording the transections from the field, and a vertical audit process named as MANDAT which conducts frequent surprise audits at warehouses and offices and has an in-house commodity care and pest management wing. The storage losses in warehouses calculated as the difference between weight of inward quantity and outward quantity. The higher losses noticed in December 2018(473.55 MT), April 2019 (461.55 MT) and June 2019 (413.65 MT). For the reduction of storage losses, NBHC do the better practices as like fumigation, time to time cleaning of warehouses, using good packing materials etc. Also the warehouses have guards and double lock and key system, which avoid theft attack. The study of marketable and marketed surplus of Food Grain showed that 83.11 per cent of total production of Food Grain was available for selling after deduction of self uses, animal feeding uses and seeds. The per cent of marketable surplus $(83.11 \%)$ and gross marketed surplus $(80.82 \%)$ didn't have too much difference which indicates that farmers are not able to stock their produces or they are not interested to stock because they need instant money for the sowing of next crop or household uses. The difference between gross marketed surplus (80.82\%) and net marketed surplus $(79.75 \%)$ indicates that Food Grain producer farmers were not purchasing.

\section{Introduction}

Warehousing plays a very vital role in promoting agricultural marketing, rural banking and financing and ensuring food security in the county. It enables the markets to ease the pressure during harvest season and to maintain an uninterrupted supply of agricultural commodities during off season. Hence, it solves the problems of glut and 
scarcity, which are the usual problems in agricultural marketing. Though warehousing is an independent economic activity, yet is closely linked with production, consumption and trade. Development of agro-processing, agricultural marketing needs a strong warehousing system. Warehousing is the most important auxiliary service for the development of trade and commerce. There had been a lack of sustained investment in the warehousing sector. The private sector initiatives were small and sporadic in this sector. Besides, most of the private sector warehousing capacities available in the country were of poor quality, small, fragmented and did not meet the requisite infrastructure standards Warehousing is a capital intensive sector and without availing finance from banks and other financial institutions, warehousing facilities cannot be created by the entrepreneurs. Besides, land requirements for construction of the warehouses are difficult to meet now-a-days due to the high cost of land. Although 100 per cent FDI and some benefits are allowed for the warehousing sector, there has been moderate growth in the private warehousing sector. About 80 per cent handling and warehousing facilities are not mechanized and traditional manual methods for loading, unloading and handling of foodgrains and other commodities are used. However, the warehouses which are mechanized have just forklifts or hydraulic hand pallet trucks. These numbers clearly indicate that there is an acute shortage of organized and good quality warehousing and storage infrastructure in the country, for both, agricultural and nonagricultural commodities. (Anon., 2012)

\section{Materials and Methods}

Convenience sampling method will be used to survey the Farmers in Jaipur district. Convenience sampling method is a type of non-probability sampling which involves the sample being drawn from a part of population close to hand. That is, a sample population selected because it is readily available and convenient. The advantages of this type of sampling are the availability and quickness with which data can be gathered. The disadvantages are the risk that the sample might not represent the population as a whole, and it might be biased by volunteers. 50 farmers were selected from 10 villages of Jaipur district like a share of different marketing channels, most importantly the comparison between regulated and unregulated markets for the commodities under study.

\section{Analytical framework}

\section{Marketed and marketable surplus}

The marketable surplus is a theoretical ex ante concept which represents the surplus which the farmer/producer has available with himself for disposal once the genuine requirements of the farmer of family consumption (retention + purchase), payment of wages in kind, feed, seed wastage and purchases have been met. The marketable surplus was computed by the following algebraic formulas,

$\mathrm{MS}=\mathrm{P}-\mathrm{C}$

Where MS = Marketable surplus, $\mathrm{P}=$ Gross production in the year,

$\mathrm{C}=$ Total requirements in the same year for family consumption (retention + purchase), payment of wages in kind, feed, seed, barter, payment of loan/irrigation and physical losses/wastage in storage/ transportation/ threshing.

Gross Marketed Surplus = Quantity actually Sold/Actual Sales

Net Marketed Surplus = Actual Sales - Net Purchases 


\section{Results and Discussion}

\section{Storage losses in the warehouse of NBHC}

In the professional warehouses business, storage losses can be defined as the weight difference between inward quantity and outward quantity. It can be occurred due to following reasons.

Due to moisture losses

Due to insect and pest infection

Due to sample collection process

Due to improper mid storage maintenance

Due to man made mistakes

Due to damages in storage structure

Due to improper bagging

Due to theft

Due to germination in stored grains during storage in rainy season

Storage losses can be calculated as difference between quantity inward and quantity outward. The difference between weight of inward quantity and outward quantity can be named as warehouses storage losses. On the basis of the secondary data collected from NBHC officials, storage losses in the warehouses are showed in Table 1. The higher losses noticed in April 2018 (23.06\%) and Feb 2019 (30.40\%).

During the study, it is observed that the storage losses in NBHC's warehouses cannot be specified in any trend or average as there is no fixed duration between of stock inward and outward. Sometime owner take only a portion of their stored commodity and remaining quantity remain in the warehouse. It is not necessary that complete stock retain at one time only.

Seasonality in inward quantity is subject to change regularly every year as a result of changes in season. These variations may be primarily due to the seasonal production, price variations of commodities, demand of processed products, requirement of protection for the commodities etc.

Table.1 Storage losses in warehouses (\% of total losses in year)

\begin{tabular}{|c|c|c|c|c|c|c|}
\hline Month & Barley & \multicolumn{3}{|c|}{ wheat } & \multicolumn{2}{|c|}{ Bajra } \\
\hline & $\mathbf{2 0 1 8}$ & $\mathbf{2 0 1 9}$ & $\mathbf{2 0 1 8}$ & $\mathbf{2 0 1 9}$ & $\mathbf{2 0 1 8}$ & $\mathbf{2 0 1 9}$ \\
\hline January & 0.01 & 2.59 & 0.00 & 0.01 & 0.03 & 0.06 \\
\hline February & 0.23 & 5.66 & 0.10 & 4.54 & 0.13 & 0.16 \\
\hline March & 0.15 & 19.37 & 0,13 & 17.26 & 0.15 & 0.19 \\
\hline April & 0.13 & 23.06 & 22.05 & 20.04 & 24.07 & 21.09 \\
\hline May & 8.01 & 4.12 & 7.01 & 3.09 & 9.03 & 11.02 \\
\hline June & 13.50 & 9.05 & 14.44 & 11.4 & 16.35 & 14.20 \\
\hline July & 30.32 & 0.16 & 35.33 & 0.19 & 37.24 & 26.19 \\
\hline August & 17.56 & 0.21 & 19.46 & 0.33 & 17.23 & 0.42 \\
\hline September & 10.55 & 2.39 & 12.36 & 3.29 & 14.28 & 6.13 \\
\hline October & 2.19 & 5.08 & 3.22 & 7.09 & 9.07 & 10.07 \\
\hline November & 4.10 & 4.66 & 5.19 & 6.32 & 8.11 & 9.04 \\
\hline December & 13.24 & 23.65 & 15.26 & 24.45 & 16.14 & 26.12 \\
\hline
\end{tabular}


Index of seasonal variation in Inward Quantity (2015 to 2019)

\begin{tabular}{|c|c|c|}
\hline No. & Month & Seasonal Indices \\
\hline $\mathbf{1}$ & January & 8.42 \\
\hline $\mathbf{2}$ & February & 2.15 \\
\hline $\mathbf{3}$ & March & 136.47 \\
\hline $\mathbf{4}$ & April & 518.18 \\
\hline $\mathbf{5}$ & May & 213.09 \\
\hline $\mathbf{6}$ & June & 101.40 \\
\hline $\mathbf{7}$ & July & 54.46 \\
\hline $\mathbf{8}$ & August & 25.68 \\
\hline $\mathbf{9}$ & September & 10.59 \\
\hline $\mathbf{1 0}$ & October & 12.96 \\
\hline $\mathbf{1 1}$ & November & 39.33 \\
\hline $\mathbf{1 2}$ & December & 77.28 \\
\hline & Total & $\mathbf{1 2 0 0}$ \\
\hline
\end{tabular}

Fig.1

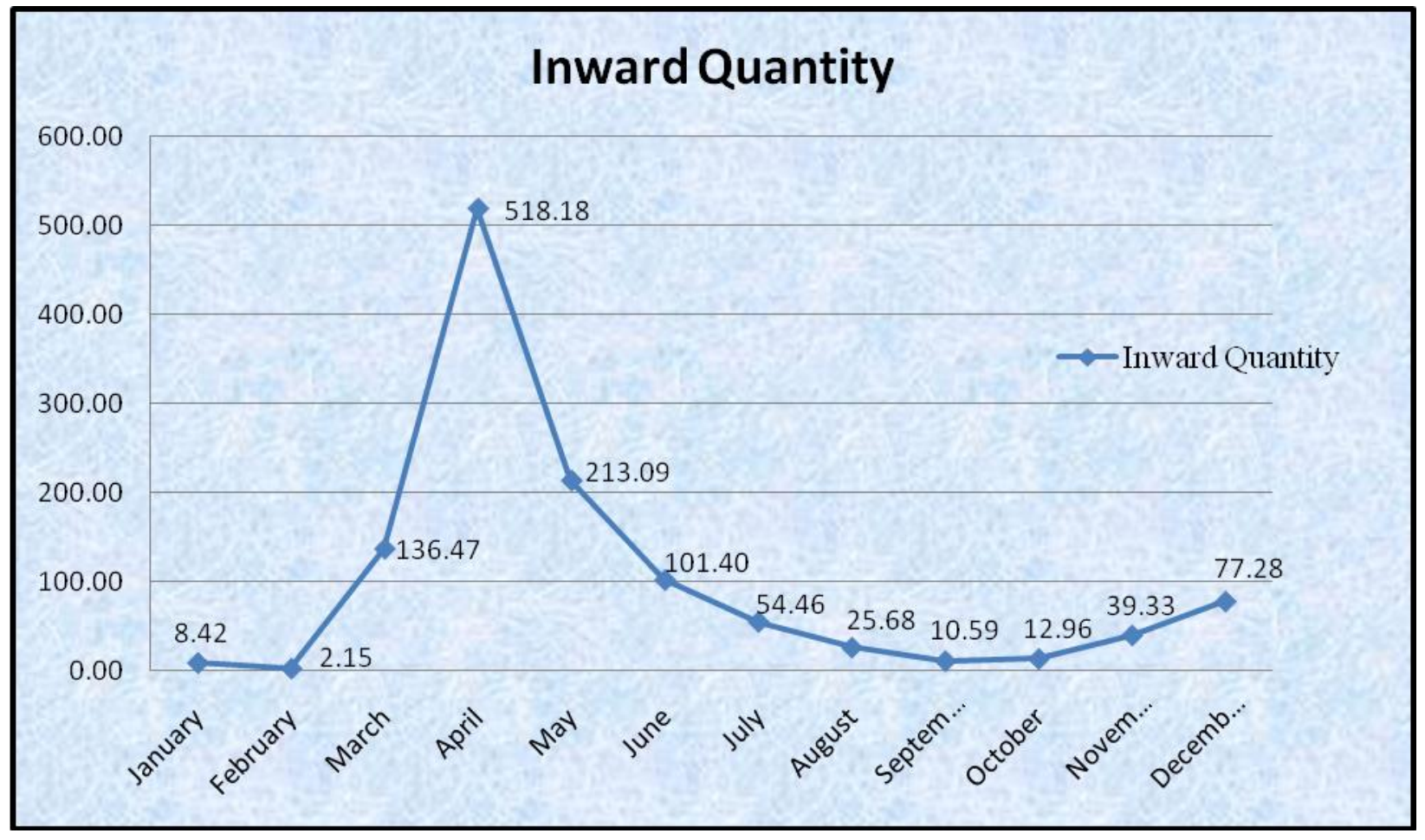


In conclusions, the highest storage losses were noticed in December 2019. Seasonal variation also found in inward quantity of commodities at $\mathrm{NBHC}^{\mathrm{ee}} \mathrm{s}$ warehouses. The highest seasonal indices were noticed in April (518.18) and the lowest in February (2.15) which indicates the highest inward of commodities in April month and the lowest in February. The results of the study of marketable surplus showed that 83.11 per cent of total Food Grain production was available for selling and the percent of gross marketable surplus didn't have too much difference which indicates that farmers are not able to stock their produces due to requirement of cash or they are not interested to stock.

\section{References}

Anonymous, 2011. Introduction of Central Warehousing Corporation Pune. Available at <http:// www.cewacor.nic.in/> last accessed on $25^{\text {th }}$ March, 2016.

Anonymous, 2012. Warehousing Development and Regulatory Authority. Annual Report 2010-2011. Available at <http:// www.wdra.nic.in/> last accessed on $25^{\text {th }}$ March, 2016.

Anonymous, 2014a. India Warehousing and Logistics. A Definitive View on Mumbai and Pune Warehousing Markets. Available at $<$ http://www.knightfrank.com research/> Last accessed on $20^{\text {th }}$ March, 2016.

Anonymous, 2014b. Commodity module: Barley. Available at http://www.kavycommodities.com/Pres entations/Commodity\%20Module_Barl ey.pdf/> last accessed on $24^{\text {th }}$ March, 2016.

Basavaraja, H., Mahajanashetti, S. B. and Udagatti, N. C. 2007. Economic Analysis of Post-Harvest Losses in Food Grains in India: A Case Study of Karnataka. Agricultural Economics Research Review, 20(1): 117-126.

Dhande, V., Masih, D., Sonkar, C. 2015. Study on Policies and Practices of Grain Warehousing System in Akola district Maharashtra. International Journal of Science, Engineering and Technology. 3(5): 1312-1315.

Shah, V. and Makwana, M. 2013. Marketed and Marketable Surplus of Major Food grains in Rajasthan. Agro-Economic Research Centre, Sardar Patel University. Available at $<$ http://www.aercspu.ac.in/> last accessed on $20^{\text {th }}$ March, 2016.

\section{How to cite this article:}

Lokendra Singh Naruka, Amit Kumar and Vaibhav. 2020. An Analysis of Warehousing Development and Trends in Storage of Major Food Grain in Nbhc Jaipur District. Int.J.Curr.Microbiol.App.Sci. 9(12): 1818-1822. doi: https://doi.org/10.20546/ijcmas.2020.912.216 